\title{
The Politics of Law in Prohibiting Physical Violence for Domestic Workers in the Largest Economy in Southeast Asia
}

\author{
Lita Tyesta A.L. Wardhani \\ Adissya Mega Christia \\ Universitas Diponegoro, \\ Semarang, Indonesia
}

DOI: https://doi.org/10.36941/ajis-2020-oo61

\begin{abstract}
Physical violence from employers is a common thing for domestic helpers, even though the right to work and decent livelihood is the right of every human being. The politics of law of prohibiting physical violence for domestic workers in Indonesia is still very weak eventhough it has strong correlation to acces to justice. This study uses a normative juridical method with an analytical descriptive approach and a case through secondary data. The results show that physical violence against domestic workers had not yet obtained a strict, consistent and coherent arrangement in terms of the the politics of law of conventions, constitutions and regulations so that access to justice for domestic workers who experienced physical violence is difficult to obtain.
\end{abstract}

Keywords: politics of law, physical abuse, domestic helpers, legal protection

\section{Introduction}

The International Labor Organization survey, ILO-IPEC shows that the total number of domestic workers in Indonesia in 2016 was 2,593,399 people (Raflis, et al., 2016) and in 2018 reaches 2,6 million people (Subekti. 2018). This amount is one of the largests in the world. The International Labor Organization Director for Indonesia and Timor Leste, Michiko Miyamoto, stated that employment as domestic workers is one of the worst working conditions groups in the world (Kumparannews, 2018). Domestic workers have not received a decent work situation as a manifestation of human rights until now. Positive law still overlaps and biased makes conditions of security in working for domestic workers continue to decline coupled with the fact that there is no legal basis that specifically guarantees welfare and protection of the domestic workers (Waridin et al., 2020). Coordinator of Jala Domestic Worker, Lita Anggraini stated that there is no state responsibility to provide protection to its citizens who work as domestic workers in the form of recognition and redistribution of their welfare who work to contribute nation's economy (Astria, 2018).

One of the rights inherent in every human being is the right for decent work and livelihood. Eligible refers to be reasonable, appropriate, proper, noble and honorable. The 1945 Constitution of the Republic of Indonesia Article 27 paragraph (2) states that each citizen has the right to work and a decent living for humanity. Article 5 of the International Labor Organization (ILO) Convention No. 189 of 2011 concerning Decent Work for Domestic Workers ensures that every Member must take 
steps to ensure that domestic workers enjoy effective protection against all types of abuse, harassment and violence. However, Indonesia is one of the countries that has not ratified the ILO Conventions so that in Law No. 13 of 2003 concerning Manpower only stated that every worker/laborer has the right to obtain protection.

The stereotype of domestic workers is as lowly work that can be done without the need for education, special skills, and can be done by everyone, and commercially low valued (Eriyanti. 2017). Domestic workers are also still close to the image of servants who must obey the employer and there are no specific devices or rules to protect domestic workers in Indonesia so that they are very vulnerable to violations of workers' rights. Violence in the broadest sense is said by Galtung, as a barrier that should be avoided which causes someone to not be able to actualize themselves properly. The barrier can actually be avoided, so in fact the violence can also be avoided if the barrier is removed. Direct violence can take many forms. In its classical form, it involves the use of physical force, such as murder or torture, rape and sexual violence, as well as beatings. Verbal violence, like insults, is also widely recognized as violence.

The increase in violence occurs in line with the needs of society, technological development and intense interaction accompanied by individualistic human nature. Humans as social beings always interact and need fellow humans and other creatures in their lives. Humans work, get married, visit each other, eat and drink and do social activities and other activities. Humans as individuals have different personalities, both different goals and outlook on life, character, region of origin, ethnicity, religion, culture, habits, and so on (Galtung. 1969). These differences can affect the process of interaction and can trigger conflicts that are dilator behind by conflict of interest and cause a reaction either in the form of a conflict of ideas or roughly in the form of violence. Acts of violence to other parties are forms of human activity which have indications against the law or contrary to applicable laws, which can be in the form of physical acts that are real to the death of the victim (Anjari' 2014). Physical violence against domestic workers falls into the category of domestic violence with characteristics including being carried out in the house, behind closed doors, with physical and/or psychological violence/torture, carried out by people who have close relations with victims and repeatedly (Setiadi, 2001).

The problem of differences in social status also often makes employers act arbitrarily in treating domestic workers. Abominable and very rude treatment as an expression of employers when breaking the law but only as an act to make a servant deterrent and not repeat his mistakes again. The weakness of the position of aides makes cases of violence against them untouched by the law (Pangestuti, 2018). The domestic worker and migrant worker have lost their autonomy and ownership and can even be said to be trapped in the status of a slave (Fadilla, 2016; Wati, 2014; Nuraeny, 2015). Previous research by Erly Pangestuti (2018) focused more on psychological violence against domestic workers. Thus, based on the background above, this paper will focus on the formulation of the political problems of the law banning physical violence against domestic workers and the extent to which access to justice can be obtained by victims amid the structure, substance and culture of law that is based on Lawrence Friedman's Theory.

\section{Consistency and Coherence of the Prohibition of Physical Violence Against Domestic Workers}

Discussions related to domestic workers became one of the topics that received attention from the ILO. In 2011, the ILO issued Convention No. 189 on Decent Work for Domestic Workers. At present there are 25 countries that have ratified it. This convention as proof that domestic workers need to get legal protection as human beings who have human rights. This Convention mandates the existence of standards for domestic workers, such as basic rights for workers, promotion and protection of the human rights of all workers, respecting and protecting basic principles and rights at work such as freedom of association and the elimination of all forms of work forced or compulsory labor, elimination of child labor, elimination of discrimination in terms of work and position. 
Effective protection from all forms of abuse, harassment and violence. Fair work conditions and decent living conditions. In addition, before domestic workers work, information must be given about the terms and conditions of work that they will live in an easily understood way. ILO Convention No. 189 of 2011 concerning Decent Work for Domestic Workers is a legal protection for domestic workers worldwide and provides a basis for providing recognition and guarantees for domestic workers to obtain decent working conditions as workers in the formal sector.

The contents of this ILO Convention are the basic rights and minimum standards that must be met in the prohibition of the treatment of violence against domestic workers, especially in Article 5 which reads Each Member must take steps to ensure that domestic workers enjoy effective protection against all types of abuse, harassment and violence. Each Member referred to in this Convention are countries which have ratified it. This process has not been carried out by Indonesia so that these values, basic rights and minimum standards cannot be incorporated into national legislation with Pancasila as a filter. At this stage, it can be seen that there is an inconsistency of the Indonesian state in realizing one of the national goals which is to protect the entire nation and the whole of Indonesian blood.

The national goals of the Indonesian people as stipulated in the fourth paragraph of the opening of the National Constitution of the Republic of Indonesia concerning the protection of the whole nation and the whole of Indonesian blood are spelled out one of them in Article 27 paragraph (2) which states that each citizen has the right to work and a decent living for humanity. Then every citizen has the right and guaranteed by the state in working for a life without physical pressure or violence. In this stage it can be seen that the founders of the nation actually have included human values for every citizen who works including domestic workers. However, the increase in the number of violence against domestic workers in Indonesia which reached September 2016 has reached 217 cases (Bayu, 2016), should encourage the government to immediately ratify ILO Convention No. 189 of 2011 concerning to strengthen the consistency and coherence of the implementation of national goals and Article 27 paragraph (2) in The 1945 Constitution of the Republic of Indonesia.

Law No. 13 of 2003 concerning Manpower also does not clearly and strongly regulate the prohibition of physical violence for workers, in this case domestic workers. Article 86 paragraph (1) letter c only states that every worker/ laborer has the right to obtain protection for treatment in accordance with human dignity and values and religious values. No further information can be found regarding this article in the Explanation although it is implied that this article is intended to provide equal treatment to workers without differentiating their status and employment relationship (Khakim, 2014). Law No. 13 of 2003 regarding Manpower is more about accommodating workers/laborers in the formal sector who have work safety standards while domestic workers as informal sector workers are full of it. Article 2 of Law No. 23 of 2004 concerning Domestic Violence states that domestic workers are also included in the household. Nonetheless, with the rampant physical violence experienced by domestic workers, the protection of domestic workers' rights as victims has not been realized as the focus of accommodation rights should fall on non-domestic workers.

The lack of consistency and coherence of the constitution, the ratification of conventions and regulations is what causes the emergence of gaps in the the politics of law of prohibiting physical violence for domestic workers, namely in their implementation and implementation. There are so many cases that are not raised to the public caused by the inconsistency and incoherence of the political law prohibiting physical violence for domestic workers from. Implementation at the lowest level between employers and domestic workers will be very vulnerable to physical violence if the legal basis above is not strong, consistent and coherent. Strong the politics of lawwill also strengthen socialization to everyone who uses the services of domestic workers as a preventive measure and reinforces sanctions imposed on anyone who commits physical violence against domestic workers as a repressive effort rather than just moral sanctions.

As a form of law reform, the ratification of ILO Convention No. 189 of 2011 and the establishment of legislation that specifically regulates the prohibition of violence for domestic 
workers is very necessary because Indonesia already has a strong basis inherited by the founders of the nation contained in national goals. In addition, the ratification of ILO Convention No. 189 of 2011 concerning Decent Work for Domestic Workers needs to be carried out by the Indonesian government, with the reason, first, the conditions of domestic workers who are still in the informal sector are considered unproductive and have no social and political value; second, there is no specific law governing the problems of domestic workers; third, the existence of a neighboring country which is also one of the largest labor exporters in Southeast Asia which has ratified the convention and provided protection for domestic workers. For the Indonesian government, ratifying this convention will both show and reflect the government's commitment to guarantee the recognition and legal protection of its citizens (Mulyanto, 2018). The existence of Indonesian domestic workers is very close to the issue of violence, both physical violence and sexual harassment to rape. ILO Convention No. 189 of 2011 provides regulations and protections for domestic workers. This convention is very important for Indonesia in accordance with the government's commitment to the international community to protect migrant workers, the majority of whom work as domestic workers. However, Indonesia does not explicitly support the need for the protection of domestic workers (Farida et al., 2019).

In the concept of national interest, it is explained that for the survival of one country, the state must meet the needs of its country in other words achieving its national interests. With the achievement of national interests, the country will run stably, both in terms of political, economic, social, as well as defense and security. The role of domestic workers is very helpful for public life even though the role played by domestic workers is often not noticed by the public. In addition to contributing to public life, domestic workers are jobs that provide a greater economic contribution, not only to domestic workers' families and service users, but also to employers who do not have to take care of domestic work and continue to work in the public sector, then work matters the household is left to the domestic worker. Indonesia's interest in the ratification of ILO Convention No. 189 of 2011 is because Indonesia has a large number of domestic workers, this is one of the reasons for Indonesia to take part in the convention. In addition, Indonesia must continue to maintain its existence as a country that protects domestic workers (Anugrah \& Jamaan, 2014). The ratification of ILO Convention Number 189 of 2011 also requires the role of domestic workers in order to improve the the politics of law of prohibiting physical violence against domestic workers to create guarantees of decent work and living conditions (Silitonga, 2014). Domestic workers can proactively urge the government to immediately ratify.

\section{Access to Justice as Crucial Issue for Domestic Worker Legal Protection}

Access to justice is one of the crucial issues for Indonesia as a state of law. Access to justice is open to all migrant workers and domestic, formal and informal. Workers in general experience problems in accessing justice so Indonesia, which holds constitutional principles, is committed that all people have equal rights before the law as a form of justice for all. However, in reality, not everyone can access justice. The weak, vulnerable, financial and marginalized are the most often experiencing difficulties in accessing justice, one of which is the domestic workers. One example of victims is Eka Febriyanti, a domestic helper who get violence from her employer in Bali, Indonesia. Eka has so far been able to sue her employer based on Law No. 23 of 2004 concerning Domestic Violence because there are no instruments that lex specifically and pro-people are protecting domestic workers from violence. However, she has difficulty accessing justice because they are under a state of inconsistency and incoherence in the prohibition of physical violence against employer pressure by employers.

Access to justice has several aspects. The first aspect of access to justice is fair and pro-people law. The law in this case is manifested in legislation in writing. The absence of laws and regulations specifically regarding the prohibition of violence for domestic workers has prevented access to justice. The employer in some cases can only be prosecuted by Law No. 23 of 2004 concerning Domestic Violence. This is clearly unfair because employee's and employer's relationship is an 
employer and domestic work relationship not a familial relationship, although they are living in the same house. Thus, the positive law used for perpetrators of physical violence against domestic workers is not yet pro domestic workers as a weak party.

The second aspect is legal literacy. Legal literacy is closely related to all forms of socialization and legal education, both directly and indirectly, for example by creating legal slogans inherent in the hearts of the people. Legal socialization and counseling is specifically intended to convey or inform the law to people who do not know the law. Because ideally every citizen must know and be aware of the law early on (Jawardi, 2016). Domestic helper who is under employer pressure is very difficult to get legal literacy on what she is going through. At the same time the employer is also not legal literate because it treats domestic workers who are required to service improperly and inhumanely. Therefore, that in the prohibition of physical violence against domestic workers who must get legal literacy are both parties both employers and domestic workers. The third aspect is legal identity. Legal identity in this case is identification such as ID card, Driving Lisence and Passport. In this case there was no explanation as to whether the employer detained the identity of the domestic worker so as not to escape.

The fourth aspect is legal assistance. Legal assistance in this case can be obtained through the protection of the Witness and Victim Protection Agency. The state is responsible for the protection of human rights as clearly stated in Article 28I paragraph (4) of the 1945 Constitution of the Republic of Indonesia which states that the protection, promotion, enforcement and fulfillment of human rights are the responsibility of the state, especially the government. Law No. 13 Year 2006 concerning the Protection of Witnesses and Victims regulates an institution that is responsible for handling the protection and assistance of witnesses and victims, which is called the Witness and Victim Protection Agency that has the duty and authority to provide protection and assistance to witnesses and victims. The scope of protection is at all stages of the criminal justice process, so that witnesses and/or victims feel safe when providing information (Tuage, 2013).

Access to justice can also be reviewed from the legal system theory by Lawrence M. Friedman (1975) which states that the legal system consists of a set of legal structures, legal substance in form of legislation and legal culture. In Indonesia speaking of the legal structure, it refers to the structure of law enforcement institutions, such as the police, prosecutors and courts. In this case the legal structure is seen from the police and Witness and Victim Protection Agency. Another aspect of the legal system is its substance (Ali, 2002; Diamantina \& Lita Tyesta, 2019). Substance is the rules, norms, and patterns of real human behavior that are in the system. The substance of the law concerns the applicable laws and regulations which have binding power and become guidelines for law enforcement officers. The statutory regulations used in this case are Law No. 23 of 2004 concerning Domestic Violence.

Law No. 13 of 2003 concerning Manpower in article 1 paragraph (5) concerning employment relations is the relationship between employers and workers/laborers based on work agreements that have elements of work, wages and orders. This is precisely where the problem lies whether the employer's position can be compared to an entrepreneur who is clearly a legal entity. Besides the dispute settlement mechanism because the institution authorized to settle disputes or who have absolute competence in the Manpower Act is an industrial relations court. This institution cannot accept disputes between domestic workers and employers, because of different legal interpretations. With these problems, the Manpower Act does not reach out to domestic workers so that the provisions contained therein cannot regulate the problems of domestic workers (Wati, 2014).

Legal culture concerns legal culture which is the attitude of humans, including the legal culture of law enforcement officials, towards the law and legal system. A poor legal culture is seen in this case, namely the physical abuse of employers against weak domestic workers. No matter how well the legal structure is structured to carry out the established legal rules and as well as any quality of legal substance created without the support of a legal culture by people involved in the system and society, law enforcement will not run effectively.

These three aspects according to Lawrence Friedman are a unity in supporting the system to 
build good law in a country (Saifullah, 2007). All three must work together because they are interrelated. In this case there are still inaccuracies in the use of Law No. 23 of 2004 concerning Domestic Violence as a legal substance and bad legal culture of employers who apply arbitrarily to subordinates in this case domestic workers. Aspects of this theory together with aspects of access to justice can be used to create law reforms prohibiting physical violence against domestic workers.

\section{Conclusion}

The the politics of law of prohibiting physical violence against domestic workers experienced inconsistencies and incoherence because even though it has been stated in the constitution as a national goal and the rights of all citizens, Indonesia has not ratified ILO Convention No. 189 of 2011 which is very important in protecting the rights of domestic workers due to violence more and more physical things happen. As a result there are no laws and regulations which specifically regulate the prohibition of violence against domestic workers. Law No. 13 of 2003 concerning Labor does not protect informal sector workers and does not regulate strict sanctions and so far cases of physical violence against domestic workers still use Law No. 23 of 2004 concerning Domestic Violence which emphasizes domestic workers not as workers but as a household member. In this case, law reform supported by related stake holders is needed.

\section{References}

Ali, A. (2002). Legal Deterioration in Indonesia [Indonesian]. Jakarta: Ghalia Indonesia.

Anjari, W. (2014). The Phenomenon of Violence as a Form of Crime (Violence) [Indonesian]. Journal of Widya Yustisia 1(1), 42-51.

Anugrah, D. P., \& Jamaan, A. (2014). Indonesian Interest in International Labor Organization (ILO) Convention No.189 [Indonesian]. Online Journal of Social and Political Science Students in Riau University, 1(2), 1-15.

Astria, D. (2018, 10 March). Jala PRT: Negara Abaikan Kesejahteraan PRT. Retrieved Feb 26, 2020 from https://www.industry.co.id/read/27884/jala-prt-negara-abaikan-kesejahteraan-prt

Bayu, D.J. (2016, Sept. 9). Hingga September 2016, Kekerasan terhadap PRT Capai 217 Kasus. Retrieved July 7, 2019 from https://nasional.kompas.com/read/2016/o9/15/16403781/hingga.september.2016.kekerasan.terhadap.prt.capai.217.k asus

Diamantina, A., \& Lita Tyesta, A.L.W. (2019). Responding to beginner voters in general elections: Between situational aspects and political actualization. International Journal of Scientific and Technology Research $8(11), 2005-2007$

Eriyanti, L. D. (2016). Empowering Women Domestic Workers: Violence Analysis and Prevention Strategies. Proceedings of the Faculty of Social Sciences, University of Jember, 2016, 2017, 67-79.

Fadilla, N. (2016). Upaya Perlindungan Hukum Terhadap Anak Sebagai Korban Tindak Pidana Perdagangan Orang. Jurnal Hukum dan Peradilan, 5(2), 181-194.

Farida, E., Rahayu, \& Wijaningsih, D. (2019). Politics and legal philosophy of indonesian migrant worker protection: Case study in Malaysia. International Journal of Scientific and Technology Research 8(11), 20022004

Friedman, Lawrence M. The legal system: A social science perspective. Russell Sage Foundation, 1975.

Galtung, J. (1969). Violence, Peace and Peace Research. Journal of Peace Research, 6(3), 167-191.

Jawardi. (2016). Legal Culture Development Strategy [Indonesian]. De Jure's Legal Research Journal, 16(1), 1-29.

Khakim, A. (2014). Fundamentals of Indonesian Labor Law [Indonesian]. Bandung: Citra Aditya Bakti.

Kumparannews. (2018, 9 March). Mempertanyakan Peran Negara atas Nasib PRT. Retrieved July 7, 2019 from https://kumparan.com/kumparannews/menggugat-negara-sebagai-pelaku-kekerasan-terhadap-prt

Mulyanto. (2018). The Urgency of the Ratification of the Decent Work Convention for Domestic Workers: Efforts to Increase Protection [Indonesian]. Law: Journal of Law, 1(1), 109-133.

Nuraeny, H. (2015). Pengiriman Tenaga Kerja Migran Sebagai Salah Satu Bentuk Perbudakan Modern dari Tindak Pidana Perdagangan Orang. Jurnal Hukum dan Peradilan, 4(3), 501-518.

Pangestuti, E. (2018). Victims of Psychological Violence Against Psychic Domestic Helper [Indonesian]. Yustitiabelen Journal, 4(1), 27-49. 
Raflis, R. I., Rochaeti, N., \& Wijaningsih, D. (2016). Perlindungan Hukum Bagi Pekerja Rumah Tangga Perempuan Korban Tindak Kekerasan. Diponegoro Law Journal, 5(3), 1-26.

Saifullah. (2007). Reflection of Legal Sociology [Indonesian]. Bandung: Refika Aditama.

Setiadi, E. (2001). Legal Protection for Women from Violence [Indonesian]. Mimbar: Journal of Social and Development, $17(3), 338-354$.

Silitonga, N. (2014). The effectiveness of ILO Convention No. 189 Against Filipino Domestic Workers [Indonesian]. Online Journal of Social and Political Science Students in Riau University, 2(1), 1-10.

Subekti, R. P. (2018). The Urgency of Ratification of the International Labor Organization Convention: Perspectives on the Protection of Child Labor in the Household Sector [Indonesian]. Journal of Udayana's Masters of Law, 7(1), 24-36.

Tuage, S. N. (2013). Legal Protection of Witnesses and Victims by the Witness and Victim Protection Agency (LPSK) [Indonesian]. Lex Crimen Journal, 2(2), 56-64.

Waridin, W., Dwiyanto, B.M., Saraswati, R., Mafruhah, I. (2020o. Formulation of problem-solving design for indonesian informal sector migrant workers towards post-placement independence: Case study in Malaysia. Research in World Economy 11(1), 115-122.

Wati, B. E. (2014). Dimensions of Legal Protection for Domestic Workers in the Era of Industrialization [Indonesian]. Palastren Journal, 7(1), 153-168. 